\title{
GCU
}

Glasgow Caledonian

University

University for the Common Good

\section{Reading Elinor Ostrom through a gender perspective}

\author{
Lapniewska, Zofia
}

Published in:

Feminist Economics

DOI:

10.1080/13545701.2016.1171376

Publication date:

2016

Document Version

Author accepted manuscript

Link to publication in ResearchOnline

Citation for published version (Harvard):

Lapniewska, Z 2016, 'Reading Elinor Ostrom through a gender perspective', Feminist Economics, vol. 22, no. 4, pp. 129-151. https://doi.org/10.1080/13545701.2016.1171376

\section{General rights}

Copyright and moral rights for the publications made accessible in the public portal are retained by the authors and/or other copyright owners and it is a condition of accessing publications that users recognise and abide by the legal requirements associated with these rights.

Take down policy

If you believe that this document breaches copyright please view our takedown policy at https://edshare.gcu.ac.uk/id/eprint/5179 for details of how to contact us. 
Dr. Zofia Łapniewska

zofia.lapniewska@uj.edu.pl

Feminist Economics, ROUTLEDGE

http://dx.doi.org/10.1080/13545701.2016.1171376

\title{
READING ELINOR OSTROM THROUGH A GENDER PERSPECTIVE
}

\begin{abstract}
This paper concentrates on the scientific work of Elinor Ostrom (1933-2012), who for more than forty years carried out theoretical and empirical research on common-pool resources. Ostrom theorizes that the commons often prevent resource exhaustion more effectively than the state, international institutions, or private owners. However, one of the foundations of commons, as an alternative program to the private-state dualism, ought to be the principle of equality that includes a gender perspective in theory and practice. The goal of this article is to provide thoughtful ways of incorporating gender in economic research from the viewpoint of feminist epistemology and to indicate the place of gender in Ostrom's work. The methodology of this study could be used for reading economic publications through a gender perspective as well as for inspiring economists to use both gender as a category of analysis and gender-sensitive language in their theoretical and empirical studies.
\end{abstract}

\section{KEYWORDS}

Elinor Ostrom, commons, gender economics, content, discourse analysis

JEL-codes: B31, B49, B54

\section{INTRODUCTION}

Only a few women have gained prominence in the history of economic sciences. Among them is Elinor Ostrom, the first and, thus far, the only woman Nobel Memorial Prize laureate 
in that field. Shortly after she was announced as the prizewinner, economists began to discuss which economic currents and schools are represented in her work. For a feminist economist such as me, the more important question was whether her achievements have any significance for gender equality, or at least, whether the currents her studies became part of are in line with the principles of feminist economics. Situating Elinor Ostrom's work in a particular place within the wide range of disciplinary boundaries is the first step toward determining her views. Although her achievements are mainly associated with institutionalism, my analysis shows that her work cannot be explicitly assigned to any of the modern institutionalist schools. Ostrom defines institutions as the regulators of human actions, constituted and reconstituted by rules, norms, and shared strategies (Sue E. S. Crawford and Elinor Ostrom 1995); therefore, she might be considered as representing the New Institutional Economics (also called Rational Choice Institutionalism). On the other hand, Ostrom's perspective also focuses on the property rights, transaction costs, contracts, and game theory (Harold Demsetz 1967; Oliver E. Williamson 1975; Douglass C. North 1990), and is therefore closer to the neoclassical (individualistic) approach than to the theory of social construction. Ostrom explicitly separates herself from that association:

Neoclassical economics and non-cooperative game theory have usually assumed that rational egoists are the only type of player that scholars need to assume in order to generate useful and validated predictions about behavior. Substantial research in nonmarket experimental settings now provides strong evidence that in addition to rational egoists, many settings also involve "strong reciprocators," who are motivated by both intrinsic preferences and material payoffs. (Elinor Ostrom 2005a: 253)

Here Ostrom not only questions assumptions found in neoclassical models, but she emphasizes the value of empirical research. As a political scientist she points out that in action situations the role of culture is one of the key elements in solving social dilemmas. This very fact situates her closer to the Sociological Institutionalism. The organizational theory developed by the Sociological Institutionalism draws on the notion of culture as a system of symbolic interpretations, cognitive scripts, and moral templates that unite human thought and action. It could be then surmised that understanding institutions goes beyond laws, procedures, and norms and provides a basis for community-based knowledge (Walter W. Powell and Paul J. DiMaggio 1991). There is also the New Institutionalism, based on a social constructivist position (Arild Vatn 2005: 25), which perceives institutions as choice sets that influence individuals with regard to their abilities, ideals, and needs. These two approaches are very much present in Elinor Ostrom's work. She greatly appreciates Amartya 
K. Sen's contribution to the social choice theory $(1974,1977)$ and often refers to his observations on collective actions and individuals following the norms of fairness, reciprocity, and trustworthiness in social dilemma situations, contrary to the predictions of rational choice theory (Elinor Ostrom 2000). She calls for the reconstruction of the basic theories on collective action and inclusion of context-oriented views of human behavior (Elinor Ostrom 2005a: 259). Ostrom's academic work also suggests new modes of studying environmental problems, which are areas of growing concern for feminist economists (Elinor Ostrom 2009a, 2010). Still, these arguments do not guarantee that a gender-sensitive perspective is included in her work, nor do they entail adopting a critical attitude toward existing divisions between men and women. For this reason the premise of my in-depth gender analysis of Ostrom's publications is to show if and how a gender perspective is represented in her oeuvre and what solutions promoting women's social and economic advancement she puts forth.

\section{GENDER PERSPECTIVE AND THE COMMONS}

For the purpose of this research, gender is defined as a social construction of identity, assigning different roles, rights, and opportunities to people, depending on their sex (Janice Peterson and Margaret Lewis 1999). Gender can be understood as creating patterns of difference and domination through distinctions (both perceptual and material) between women and men which is integral to many societal processes including production and reproduction as well as consumption and distribution (Joan Acker 1992). It is important to recognize that gender relations affect planning, production, family well-being, household security, and many other aspects of life (Heidi Bravo-Baumann 2000). In many parts of the world, women are involved in grassroots environmental activism and constitute a forefront of culture and community protection. Since they are also primary subjects to care, productive, and reproductive work, it is necessary to include gender analysis in the theory of commons. Women, more often than men, depend on access to collective natural resources and are frequently adversely affected by the privatization of these resources. By objecting to such privatization, women often act in their own best interest (Silvia Federici 2004, 2012). Women are the subsistence farmers of the world (Marilee Karl 1997). They also constitute a major lender-borrower group in the money commons based purely on trust (for example, in Cambodia and Senegal), they struggle to collectivize reproductive labor, protect each other 
from poverty and state or individual violence (Leo Podlashuc 2009). Recent research shows that in the communities in which women and men enjoy a relatively equal status, the poor climb out of poverty more quickly, economies tend to grow faster and the well-being of women, men, and children is enhanced (Sylvia Chant 2003).

Feminist economists argue that by including gender, economic analysis has a potential to transform disciplinary paradigms not only by adding the topics that influence women's lives and experiences, but also by examining the role of gender in shaping values and premises that guide scholarly enquiry (Marianne A. Ferber 1997). A deeper insight into the implicit assumptions of gender economics helps to avoid the biases and distortions in disciplinary accounts. "Gender-neutral” methodologies, concepts and theories can be read as concealing, protecting, and naturalizing gender privilege (Janice Peterson and Margaret Lewis 1999). Conversely, a feminist analysis is an adoption of the feminist perspective in a given field of enquiry and cannot be carried out simply by adding the category of sex as a variable. Feminist researchers focus on women as a social category as well as individuals, aiming to create a social change and represent human diversity (Shulamit Reinharz 1992). In economic theories, models and policies this feminist perspective promotes the image of economics as primarily concerned with everyday life and brings us closer to understanding human behavior in terms of both choice and materiality. A gender-inclusive approach can result in less partial and distorted accounts of people's actual lives in all their diversity. In particular, a gender viewpoint is essential in the theory of commons, as commons may be perceived as an alternative to capitalist individualism and isolation. The incorporation of gender can lead to the construction of economic theories that would illuminate economic realities and promote socially progressive policies. At the same time, incorporating a gender dimension in research and models devoted to the commons can give rise to a new debate on equal and effective management of resources. The feminist epistemology can be an important and unifying framework in this discussion. As an approach, it emphasizes gender as an analytic category in scientific debates as well as in norms and practices that are unique to governing the commons. As Lorraine Code points out:

Feminists are engaged, albeit from different theoretical positions, in demonstrating how epistemologies - often tacitly - carry with them a potential either to sustain a social-political status quo or to promote emancipatory ends. Tracing the effects of theories of knowledge in the world where knowledge is sought and made, feminist and other critiques of epistemology have demonstrated that epistemic agendas and social-political commitments are inextricably intertwined and mutually constitutive (Lorraine Code 1996: 1). 
This method is in line with a broader perspective, going beyond only gender as but one component in the complex social construction of identity, hierarchy, and difference, along with such aspects as class, disability, race, ethnicity, religion, and sexuality. A combination of all of these factors determines the social, cultural, and economic situations of individuals (Nancy Folbre 1994). For this reason, I refer to these dimensions as well as to gender in the analysis of Ostrom's texts in the following section.

\section{ELINOR OSTROM AND THE COMMONS}

Ostrom carried out a significant number of theoretical and empirical projects on commonpool resources such as forests, fisheries, irrigation systems, grazing ranges, and groundwater basins (Elinor Ostrom 1965, 1990, 2005a, 2005b). This research resulted in the publication of more than 100 monographs, book chapters, and scientific articles dedicated to common-pool resources. Meeting and observing local communities that relied on ecosystems over a long period of time, she described the institutions they created as successful conflict-resolution mechanisms. Her extensive research on commons demonstrates that in frequently occurring or repetitive situations structured by institutions, individuals cooperate to sustain a long-term and productive use of natural resource systems as well as to reap collective benefits from the community-owned resource. However, in some settings they fail and a different governance structure (either a state or a market one) appears to be more efficient. The outcome depends, among others, on whether specific institutional arrangements harmonize with local culture and the manner of their implementation. Cultural biases and inaccurate accounts of social behavior often lead to unsuccessful resource preservation and a decline in well-being of local actors.

Ostrom agreed that "the tragedy of commons" (Garrett J. Hardin 1968) - indicated by environmental degradation - may happen for various reasons. Nevertheless, a number of observations and research projects conducted by her suggest that local actors can overcome the dilemmas of collective action and sustain common-pool resources (Robert Costanza, Bobbi Low, Elinor Ostrom, and James Wilson 2000). This orientation toward the advantages of community ownership opens a space for a new debate on effective governance of other resources such as housing or public spaces. Ostrom presented a set of principles that help to account for successful governing of the long-enduring commons. The first principle, clearly 
defined boundaries, was a response to Hardin's description of an open-access resources exhaustion. She also recommended: setting collective-choice arrangements; congruence between appropriation, provision rules, and local conditions; monitoring and graded sanctions; conflict-resolution mechanisms; and minimal recognition of rights to organize (Elinor Ostrom 1990). According to Ostrom, adopting such design principles facilitates the sustainability of common-pool resources and related institutions as well as explains why participants are willing to conform to the operational rules, monitor each other's conformity and replicate the institutions across generational boundaries. However, various collectives and communities question some of these principles, for example the necessity of mapping out user and resource boundaries and imposing sanctions on those community members who violate the rules. The lack of boundaries applies to free exchange networks or time banks such as those described by Irene Sotiropoulou (2012) - the Greek Exchange Network of Chania (475 members (61 percent of women) in 2012) and the Charise-to Free network (601 members (52 percent women) in 2011) as well as the German Tauschringe (221 networks operating in the country) described by Michael Wünstel (2013). They exist online and serve as channels for handing over goods and services or exchanging them for other goods and services (barter) in the present or in the future. Exchanges take place without the use of any official currency, however sometimes the networks use units representing value to calculate the transactions, such as the Robust Complementary Community Currency System (ROCS) or Time Dollars. Many commons, operating not only in digital but also physical space, deliberately avoid using sanctions, finding them less effective than communication. This approach was confirmed by field observations and laboratory experiments conducted by Roy Gardner, Elinor Ostrom, and James Walker (Elinor Ostrom 2006). They point out that faceto-face communication, especially repeated, is extremely successful in increasing joint returns, but its effectiveness can be restrained by economic inequalities based on wealth and social distance between the group members (Elinor Ostrom 2006; Juan Camilo Cardenas 2000). In turn, investigating sanctions shows that if the field setting is self-organized, the exogenously authorized sanctions are rarely imposed, but punishments for disobeying rules designed by the group members are administered very quickly (Marco Casari and Charles Plott 2003; Elinor Ostrom 2006). The framework discussed above is being debated, but still constitutes a starting point for establishing long-enduring commons and is an inspiration for collectives and communities in governing their common goods.

In addition, the experiments demonstrate that cooperation in commons is enhanced 
mainly by reciprocity, individual reputations and trust (Elinor Ostrom 1998), and that the endowments introduced as common property can lead to greater cooperation and trust than private property (Michael Cox, Elinor Ostrom, and James M. Walker 2007). The emphasis on collective work, establishing norms, rules, and shared strategies for improving conditions of everyday life of actors as well as sustaining the resources they govern over a long period of time is noticeable in Ostrom's writings. For this reason, commons and their governance can be perceived as an alternative idea of social organization and foundation for a new mode of production.

By and large, the community development and participatory models are often gender blind and reinforce a local patriarchal and elite control (Marilyn Porter and Ellen Judd 1999). Some models wrongly assume that interests at community level are homogenous for all its members and bring everyone equal benefits (Janet Momsen 2002). Ostrom proposed an alternative formula for managing common-pool resources but she did not analyze to a great extent the effect of applying this formula to women and men. This paper outlines the use of content and discourse analyses for reading economists' texts from a gender perspective and opens a discussion on inclusion of a gender dimension in economic models and theories, especially those dedicated to commons.

\section{READING ECONOMISTS’WORK THROUGH A GENDER PERSPECTIVE}

Feminist institutionalists (for example, Joni Lovenduski, Meryl Kenny, Fiona Mackay, and Mona Lena Krook) point out that the pecuniary culture is dualistic and gendered. The cultural and social dualisms are hierarchical and legitimize master-servant relationships. The distinctions of: man-woman, public-private, economy (market)-family, rational-emotional, competitive-nurturant, independent-dependent are only a few examples of gender dichotomies (Julie Nelson 1992; Ann L. Jennings 1993; Kathleen Thelen 2003). Economic institutionalists add that economic processes are shaped by power, compulsion, and conflict, thus the economy represents the system of power and hierarchy itself. It is for this reason that economics cannot avoid judgments and needs to have a prescriptive character (Marc R. Tool 1993). To overcome the gender dualisms, some economists concentrate on investigating and acknowledging similarities, especially when it comes to the changes of roles that the society and culture impose on women and men (Julie Nelson 2013). For example, feminist 
economists, in the discussion on the economic power, have challenged the definition of economic pursuits and cultural interpretations that prioritize "the economic," as they see gender dimensions as consisting of a blend of "economic" and "noneconomic" pursuits. They have put forth an alternative beyond the limits of dichotomy, understanding markets and economies as embedded in a matrix of culture, beliefs, and practices (Ann L. Jennings 1993). This attitude corresponds with the concept of commons and their property rights belonging to the community members of a specific culture and institutions representing it. Content and discourse analyses help to identify the qualities of these cultures in the analyzed texts, which in case of this paper are especially important with regard to gender.

Drawing on Laurel Graham's formulation, I define content analysis as a "feminist intertextual deconstruction" (1990: 3-4), understood as feminist subversive reading, pointing out what the selected texts say, omit, and hint at. This scope of research is broadened by a discourse analysis where discourse itself "refers to the totality of signs that carry meaning" (Ruth Wodak 1997: 4). Various definitions refer to verbal and nonverbal language behavior and discourse as an action. In this paper, the definition of discourse analysis is narrowed to "units and forms of speech, of interaction [in] the co-presence of speaker and listener" (Gisela Brünner and Gabriele Graefen 1994: 7-8). Discourse analysis in this case focuses on the way of addressing and anticipating gender in the language of the selected interviews. One of many types of this research is critical discourse analysis "that primarily studies the way social power abuse, dominance, and inequality are enacted, reproduced, and resisted by text and talk in the social and political context" (Teun A. van Dijk 2001: 352).

Economists who choose to employ gender-sensitive language may imply a more holistic approach in the policies and practices they propose, thereby aiming at the creation of a more egalitarian society. What might substantially contribute to the discussion on alternative solutions to women's advancement, including resources ownership and management, is the analysis of the performance of common-pool resources as an alternative to the market (private)-state dualism from a gender perspective.

\section{RESEARCH ON GENDER IN ELINOR OSTROM'S TEXTS}

In this paper I employ content analysis and discourse analysis to examine Ostrom's texts. 
Content analysis is understood as a research technique of examining artifacts of social communication in written documents (Bruce L. Berg 2007: 238-241). In the case of my research it is applied to determine the presence of concepts, themes, and sentences related to gender in the analyzed publications. For that examination I developed a coding scheme, which is introduced in Table 1. This study is later enhanced by discourse analysis that focuses on "language beyond the sentence" (Lia Litosseliti and Jane Sunderland 2002: 9) and communication of meaning of the analyzed texts in particular social contexts. Therefore, my analysis shows how gender is represented in the selected publications (especially in the interviews conducted with Ostrom) as well as how gender is socially constructed by language and context with reference to commons.

For the content analysis Ostrom's publications are broken down into the categories of word sense, phrase, sentence, and theme and examined through conceptual and relational analysis in order to address the following research question: Is gender reflected in Elinor Ostrom's texts, and if so - to what extent? For the purpose of this study I have chosen Ostrom's 102 publications from the list included in her online curriculum vitae and interviews conducted before and after she received the Nobel Memorial Prize. ${ }^{1}$ The selected documents had to meet the following criteria: written in English, written exclusively by her, ${ }^{2}$ pertaining to commons, collective actions, or institutions (not, for example, policing, which was the focus of her earlier research), accessible in the electronic format that can be processed by ATLAS.ti software. ${ }^{3}$ The selected publications fall into the following categories: books (2), chapters in books (24), journal articles (48), book reviews and presentations (17), and interviews (11).

Table 1 Explicit content analysis results ( $\mathrm{N}=102$ Ostrom texts)

\begin{tabular}{|c|c|}
\hline Category & Coding Frame: Terms \\
\hline $\begin{array}{l}\text { Women are portrayed as sex objects, on the basis of } \\
\text { their appearance instead of competences and } \\
\text { intellectual performance (for example, "a blonde"). } \\
\text { Their roles, behavior and speech are trivialized, for } \\
\text { example, "girl," "weathergirl" (showing immaturity), } \\
\text { "drama queen" (expressing emotions), or by using } \\
\text { diminutive forms. Their positions and professions are } \\
\text { judged and diminished, for example, "ladette" or } \\
\text { "career woman". }\end{array}$ & 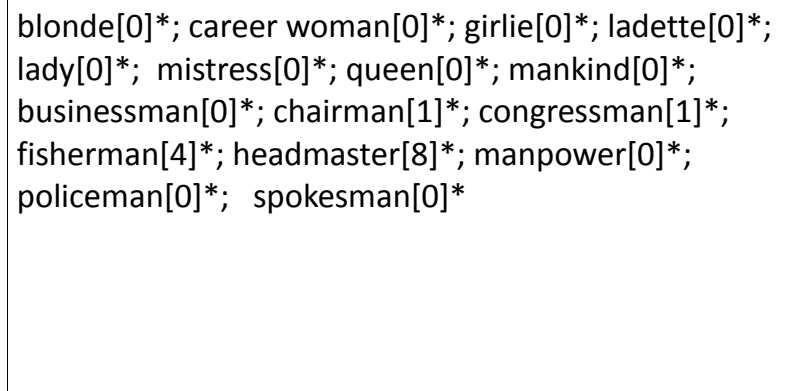 \\
\hline $\begin{array}{l}\text { Women are depicted in the essentialist roles related to } \\
\text { family, home, domestic and care work, for example, } \\
\text { "mother of three". The gender binary and inequality, } \\
\text { based on assumptions about biological sex } \\
\text { characteristics, are sustained and reinforced. The }\end{array}$ & 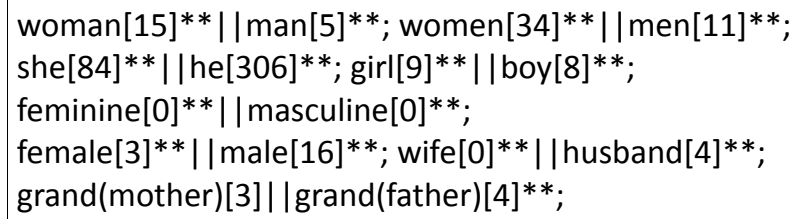 \\
\hline
\end{tabular}


androcentric vision of a society or community dominates (male privilege). sister[3]**||brother[2] ${ }^{* *}$; aunt[0]**|| uncle[0]**; niece[0]**||nephew[0]**

social[2,203] | |individual[915]; weak[62]| |strong[314]; emotion(al)[9]** | rational(ity)[689];

informal[82]* | formal[411]; equity[90]* | |

efficiency[136]; cooperative[152] | |competitive[168];

intuitive[5]* | |rigorous/analytical(ly)[99]*;

unpaid[0]* || paid[85]**;

reproduction[6]* ||production[398]

There is no reference to sex/gender in the analyzed text; instead, general terms are used, for example, "they," "them," "people," "persons," "partner."

they[3,508]; them[809]; their[3,332]; people[474]; person[196]; partner(s)[16]**; family(ies)[192]**; household[182]*; employment[14]*; (anti)poverty[11]** poor [44]**; social[2,203] economic $[1,175]$ status[17 $]^{* *}$; human[740]; humans[185]; rights[1,353]; class[58]; race[32]; ethnic(ity)[49]; religion(s)[4]; religious[18]; disability[0]; disabled[0]; handicap[0]; dysfunction[0]; impairment[0]; community[863]; communal[220]; communities[320]; members[265]; social space[4]*; identity[19]**; society[350]; sex(es)[7]

The language is more inclusive, the masculine/feminine terms are replaced with the gender-neutral ones, for example, "fireman" with "fire fighter" or "chairman" with "chair". "Ms" is used instead of "Miss" or "Mrs" and "gender" instead of "sex." A generic female pronoun is added to a male one, also in reverse order, for example, "she or he," "s/he," "women and men."

The presence of linguistic interventions, for example, "herstory," "hes," "s.he" can be observed. Certain identity words are reclaimed or their meaning is changed, for example, "queer" or "dyke" used in a positive way. The text refers to a social-cultural sexual identity as well as its production, fluidity and performativity. Sexist sentiments and irony are eliminated, for example treating "women as property," "like an object," or as a "weak sex" even in knowingly humorous way. Defiance against hierarchies, including patriarchy and chauvinism, power, domination and control, both in the public and private space (anti-sexist practices) is visible in the analyzed text. gender[21]*; he or she[26]**; she or he[0]**; sexuality[0]; equality[5] ${ }^{* *}$; diverse[525]; diversity[42]**; tolerance[1]**; emancipation[0]**; empower(ment)[10]**; feminization[0]*; maskulinization[0]*; integrate(ion)[4] ${ }^{* *}$; exclusion[119]**; inequality[5] ${ }^{* *}$; unequal[7] $]^{* *}$; inequity[3]**; social exclusion[0]*; privilege[15]**

discrimination[13] ${ }^{* *}$; anti-discrimination[0]*; intersectionality[0]**; stereotype[0]**; prejudice(s)[1] ${ }^{* *}$; marginalization [0]*; marginalized group $(\mathrm{s})[0]^{*}$; hate

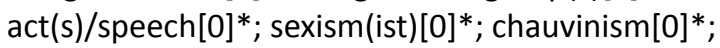
isolate(ion)[10] ${ }^{* *}$; stigma(tization) $[0]^{*}$; violence[14] ${ }^{* *}$; rape[0]*; humiliation $[0]^{*}$; anti-sexist $[0]^{*}$; herstory $[0]^{*}$; s.he[0]*; queer[0]*; transgender[0]*; feminism(ist)[0]*; sexual identity[0]*; hybrid identity[0]*; hierarchy[21]**; patriarchy[0]*; power[97]**; dominate(ion)[20]**; control[378]; public space[7]*; private space[4]*; injustice[1]**

$[\mathrm{x}]$ - number of times the term is present in the texts, automatically calculated by Atlas.ti 7

$[\mathrm{x}]^{*}$ - number of times the term is present in the texts, coded or checked manually, with relation only to Ostrom words (avoiding references and interviewers' questions)

$[\mathrm{x}]^{* *}$ - coded manually (see description of " $[\mathrm{x}]^{* \prime \prime}$ ) terms used by Ostrom only in relation to other people (not situations, structures, rules, and so on).

The reason for including interviews in the selection was their less formal language and specific issues addressed by interviewers (closer to discourse) that had the potential of exhibiting Ostrom's implicit motivations and the meanings she intended to incorporate into her work. For the explicit content analysis of the selected texts, I have prepared a list of words (see "Coding Frame: Terms" in Table 1). The wording and its interpretation were built 
on the collected work and research of many feminist linguists and economists and their key assumptions about language and gender, such as, to name just a few, Joan Acker (1990, 1992), Julie Nelson (1995), Ruth Wodak (1997), Anne Pauwels (1998), Mary Talbot (1998), Christine Christie (2000), Frank Taylor (2003), Jane Sunderland (2004), Cecilia Ridgeway and Shelley Correll (2004), and Lia Litosseliti (2006).

The initial analysis shows that Elinor Ostrom never uses expressions that portray women as sex objects or judge them on the basis of their appearance instead of intellectual performance and competencies. There are only four expressions in the analyzed texts that are omitted or replaced by their neutral equivalents by feminists today, namely "headmaster" (8), "fisherman" (4), "chairman" (1), and "congressman" (1). Ostrom uses neither subversive terms nor linguistic interventions. One of the reasons for this could be her fieldwork sensibility. She was respectful towards local people's perspectives and the ways they dealt with governing the commons. Ostrom collected evidence for complex experiences by carrying out observations and communicating with local community members and it is possible that in the process she inadvertently avoided certain words and phrases that might be misunderstood or interpreted varyingly in different cultural contexts. Words such as "blonde," "career woman," "ladette," "lady," "mistress," "queen," "mankind," or "marginalized group(s)," "hate act(s) or speech," "sexism(ist)," "chauvinism," "queer," "transgender," "feminism(ist)," "sexual identity," and "hybrid identity," which are not present in Elinor Ostrom's texts, might have no meaning (either pejorative or positive) to some groups. Also, she did not address the subject of gender equality specifically - an issue which I shall now attempt to examine in detail.

In the analyzed texts, a proportion of phrases appear in the dichotomous approach. The terms describing women and men are present to a similar extent. Despite the fact that "he" (306 appearances) appears in the selection significantly more often than "she" (84 appearances), it is important to note that in her later work Elinor Ostrom started to use the expression "he or she" (26) but not in reverse order "she or he" (0). Still, it is essential to keep in mind that women and men are not fixed monolithic categories, leaving room for human agency and indicating that this process can run in the direction of first language, then gender (Lia Litosseliti 2006: 3). The feminist point of view includes the category of gender perceived as multiple, fluid, and never complete, as "the emergence and re-emergence of the self" (Lia Litosseliti and Jane Sunderland 2002: 7). This flux enables "doing identity work" as a practice of making series of choices (Anthony Giddens 1999: 412-413). Additionally, 
Ruth Wodak comments that "what it means to be a woman or to be a man changes from one generation to the next" (1997: 4), indicating the importance of gender performance and language updates. Another matter is the multiplicity of gender identities across populations and cultural contexts and among individuals. This challenges the notion and study of essential identities of being a woman or a man and points at different femininities and masculinities (Lia Litosseliti and Jane Sunderland 2002). Judith Butler has developed this idea further, arguing for opening up "the field of possibility for gender without dictating what kind of possibilities ought to be realized" (1999: viii). Notwithstanding the diversity of the approaches above, Ostrom does not delve into any of these discussions in the analyzed texts. The most frequently used terms are: "they" $(3,508)$, "their" $(3,332)$, "rights" $(1,353)$, “community” (863), “them”(809), "human” (740), people” (474), “communities” (320), "members" (265) “communal” (220), "person" (196), and "humans" (185). These results demonstrate that Ostrom, unlike economists accepted in the mainstream economics framework, employed gender-neutral expressions. Mainstream economists are bound, to a large extent, by mathematics and aim to be objective, losing at the same time the social dimension (Julie Nelson 1996). Admittedly, Ostrom refers to the rational actor's models and makes universal assumptions in some of her work. On the other hand, she attempts to understand and present the positions and views of local actors. As a political scientist she also focuses on formulating conclusions that might be useful in drawing up policy directions and criticizes advocating general solutions (Peregrine Schwartz-Shea 2010). Be that as it may, this orientation toward practical applications of her research outcomes and taking local societies into consideration does not lead to gender representation in her work. This lack of gender perspective also applies to power and inequality issues. Despite using the words “control” (378), “exclusion" (119), "power" (97), "hierarchy” (21), “dominate(ion)" (20), and "inequality" (5), she does not problematize these aspects. The only issue in reference to "class" (58) she repeatedly returns to is "poverty" (24). It is not only the word "poor" (44) she deliberately uses in her publications, but she also exhibits particular sensitivity to this subject, pointing out the different contexts in which poverty appears. She emphasizes, "Powerful individuals within a community are frequently given further advantages (for example, control over the resources), leading to major problems in economic development. The poor and the powerless are the ones who pay the most" (Elinor Ostrom 2009b: 32). There is also a personal story attached to her sensitivity to this issue. In one of the interviews she reveals: 
I was born poor and I didn't know you bought clothes at anything but the Goodwill until I went to college. Some of our mentality about what it means to have a good life is, I think, not going to help us in the next fifty years. We have to think through how to choose a meaningful life where we're helping one another in ways that really help the Earth (Quoted in Fran Korten 2010).

This confession, combined with pointing out environmental sustainability, makes Ostrom seem very likeable and can win her many supporters. These two quotations allow me to move on from the explicit content analysis to a more contextualized interpretation of Ostrom's texts.

The short discussion of the research outcomes presented above that refers to the specific words count could be associated with the positivist definition of science, which focuses mainly on validity and reliability of research (Peregrine Schwartz-Shea and Dvora Yanow 2002). The results that show context-free generalizations derived from calculations might be shallow and sometimes misleading. For this reason, in order to answer my research question, I refer to interpretative qualitative analysis and the results acquired from a close reading of Ostrom's texts. I focus on the actual relevance of the texts to gender equality, which is also in line with the quoted definitions of content and discourse analyses.

Ostrom did not assign the essentialist phrasing to particular sexes. She used them to describe communities or institutions and their performance over time. For a long time, she did not use the terms "sex" or "gender" with regard to human beings. Before 1999 she only differentiated between the sexes of animal species described in her work dedicated to common fish and lobster fisheries. Nevertheless, in 1999 she published the paper "Coping with Tragedies of the Commons" (1999) in which "gender" appeared as one of the individual attributes of actors governing a common-pool resource, among such characteristics as age, caste, clan, class, ethnicity, and race (Elinor Ostrom 1999: 510). As Ostrom explains, these features were identified by scholars associated with the Workshop in Political Theory and Policy Analysis at Indiana University. The workshop turned out to be a very fruitful collaboration in terms of recognizing the importance of gender and other attributes in analyzing commons governance. Although in my paper, her collaborative work is not studied, I am convinced that a future project focused on reading Elinor Ostrom's coauthored work, not only from gender, but also from intersectionality perspective (Hankivsky 2012), might be exceptionally interesting. The participants of the Workshop in Political Theory collected many original case studies from all over the world in search for rules formulated by users to govern their resources effectively. These rules referred to boundaries of a resource and the 
authority of individuals to enter and appropriate its units. These characteristics of community members, which Elinor Ostrom calls "attributes,", are consistently present in her later publications. As I mentioned in the previous section, they are also linked to power relations. In her publications Ostrom focuses on the cooperation and decentralized and shared forms of power, in contrast to the Hobbesian solution or the idea of yielding to any other hierarchical authority. One of the preconditions of a decentralized power division is trust, which Ostrom mentions, but does not analyze inequalities in access to power in connection to it. Also, the description of constraints on power depending on disability, age, or gender does not make it onto the pages of her publications.

Another question relating to Ostrom's work is whether the process of othering based on culture, religion, race, ethnicity, or other features, including gender, might have taken place in the observed communities. The idea of otherness was often raised by feminist economists who referred to Simone de Beauvoir's and Georg Wilhelm Friedrich Hegel's master-slave dialectics as analogous to the power relations between women and men. The discussion on Ostrom's work could be further enriched by considering women's economic standing in particular communities in relation to the asset endowments as well as status inequalities such as legal and governance systems, capacities, vulnerabilities, and motivations of women (Joan Acker 1990; Lauren Pandolfelli, Ruth Meinzen-Dick, and Stephan Dohrn 2005).

Individual qualities and attributed social roles influenced not only the successful governance of the commons, but also the way people have created institutions. Ostrom's investigation into this subject resulted in the development of "grammar of institutions," pointing out the characteristics of norms and rules that make them effective. In the paper "Developing a Method for Analyzing Institutional Change" (Elinor Ostrom 2005b), she includes gender in this grammar for the first time.

We have developed a grammar that can be used to 'parse' each of them. For example, each rule can be parsed into five components that specify: (1) the attributes of a participant (such as age, education, gender) affected by a rule; (2) the deontic modal verb of the rule which include 'may' (permitted), 'must' (obliged), and 'must not' (forbidden); (3) where the rule aims - at the set of potential actions or the outcomes of the situation; (4) the conditions specifying when and where an action or outcome is permitted, obligatory, or forbidden, and (5) the consequences specified for not following a rule (the 'or else'). (Elinor Ostrom 2005b: 40)

The inclusion of "gender" as one of the key actors' characteristics and communicating this idea in both written and oral form (publications and conference presentations) can be 
regarded as asserting its importance. Although the quote above suggests taking into consideration the impact of institutions on women and men, it does not recognize women's and men's textured accounts of power and space to create institutions. It does not mean, however, that Ostrom did not acknowledge the importance of human agency. She criticized the powerlessness of agents in Garret Hardin's "Tragedy of Commons" (1968) and respected local institutions, often giving them privilege over the central authority or international policy directions. However, on closer inspection, Ostrom's texts showed that they lack a critical examination of the introduced concepts, including their meaning to women and men in the given communities. Ostrom also ignores the character of political regimes in which institutions are nested. They could be democracies as well as dictatorships. Furthermore, institutions can emerge either by reaching a consensus or by being based on sexism and racism, still contributing to the long-term goal of long-lasting preservation of common-pool resources. The issues pertaining to democracy on the local level as well as political equality of the community members remain unexamined in the analyzed selection of Ostrom's work.

Ostrom's scientific publications do not contain some aspects of her political views, including her attitude to gender. Yet, as Helen Longino points out in her work on feminist epistemology (1990), values do enter the processes of scientific reasoning. Thus, to identify Ostrom's beliefs, I shall now turn to the discourse analysis of Elinor Ostrom's texts, which in this research includes interviews with her. As the first woman Nobel laureate in Economic Sciences Elinor Ostrom was asked many times about the interrelation of economics and gender. In the interviews selected for the purpose of this research, she expresses the difficulties she encountered in academia:

Having lived through an era, where I was thinking of going to graduate school and was strongly discouraged because I would never be able to do anything but teach in a city college... Ah ha ha, life has changed! [...] I've attended economic sessions where I've been the only woman in the room, but that is slowly changing and I think there's a greater respect now that women can make a major contribution. (Adam Smith 2009)

This critical contemplation on women's roles and positions in the public space obviously arises from Elinor Ostrom's individual experiences and hardships she faced. In another interview she addresses admission restrictions, common in many academic fields:

Well, political sciences would admit me, but then, I think in the prefatory [review], I mentioned that they had not a woman in the department for simply years, and they admitted 4 of us in a class of 40, and it was a huge controversy that we found out. Fortunately, there were four of us because we could kind of buddy together (Margaret Levi 2010: 2). 
Encountering prejudice in enrolment was not the only problem for women with academic ambitions in those times. Julie Nelson (1996) also brings to light sexism in the process of selecting university research staff and incorporating only "valuable knowledge" in teaching programs (1996: B3), perceived as in line with the vision of the aforementioned masculinity in culture. This last feature changed slightly over time, for as Elinor Ostrom observes:

I was thrilled, I was honored as a woman, having fought a lot of my life against the presumption that women would not be professionals. I think that's changing. We now have more women graduate students in the social sciences. There were a number of women last year who received the Nobel, and so that was a good sign to the future. I don't think it will be very long, and there'll be another woman. Maybe even this year. Who knows? (Amitabh Pal 2010)

The situation has changed, although not by itself. Unfortunately, Elinor Ostrom does not refer in any of the selected texts to women's struggles, which became more and more noticeable since the second wave of feminism, not only in the academia but also in grassroots organizations and local communities. It is difficult to say why she did not embrace feminist literature when many of her contemporaries both in political sciences and economics did. When the Nobel Memorial Prize was awarded to Ostrom, Nancy Folbre in her statement for the New York Times pointed out that at the beginning of the 1970s the women's caucus of the American Economic Association acted actively to challenge discrimination, monitor women's participation in the discipline and establish the Committee on the Status of Women in the Economics Profession. At that time, Ostrom was part of a similar group in the American Political Science Association (Nancy Folbre 2009), which fact is not reflected in Ostrom's scientific work. What can be surmised is that she appreciates the role women play in governing commons. In the interview conducted in 2011 by Ann Mari May and Gale Summerfield for Feminist Economics, she addresses directly the aspect of gender in her research:

While I have not made gender a major factor affecting my analysis of common-pool resource situations, I have been very interested in observing the diversity of roles that women play in many different settings. We have gathered data, and I have encouraged many of my students to do analysis on the role of gender. They have produced some very important work. Esther Mwangi and Pam Jagger have done some very important work. They find that the role of gender differs by region (Pamela Jagger 2008; Esther Mwangi, Ruth Meinzen-Dick, and Yan Sun 2011). It is certainly the case that when women are active participants in making rules and affecting the way a commons operates that the long-term impacts are likely to be better and the equity of outcomes is likely to be much better. (Ann Mari May and Gale Summerfield 2012: 31) 
As Ostrom mentions, some of her students have included a gender perspective in their studies. Additionally, the fieldwork conducted by Olaf Westermann, Jacqueline Ashby, and Jules Pretty (2005) indicates that if women were to have an influence on establishing institutions as members of groups, solidarity and conflict resolution abilities would improve. This shows that institutions themselves are gendered and can either reinforce or challenge the existing social roles. Her personal experiences could have been transferred to the research on different roles, rights, and opportunities for women in communities governing common-pool resources. Such inclusion could encompass the existing power relations that affect local economies, that is patterns of planning, production, reproduction, consumption, and distribution, as well as family well-being, household security, and many other aspects of life. Regrettably, Ostrom did not investigate these subjects in the analyzed publications. Still, her work is unique, cutting edge and different than that of her peers, eschewing the traditional disciplinary pigeonholes. It is these merits that I intended to emphasize in this paper in taking up the complex task of trying to determine the place of gender in a selection of her publications.

\section{DISCUSSION AND DIRECTIONS FOR FUTURE RESEARCH}

The ideas, research outcomes, and concepts presented here are meant as an introduction. Further research on Ostrom's coauthored work from, for instance, the intersectionality perspective, might be an appealing direction for future studies. Secondly, a gender-focused investigation into institutions might also be a subject of a detailed analysis. As Silvia Federici observed, "grassroots women's communalism today leads to the production of a new reality, it shapes a collective identity, it constitutes a counter-power in the home and the community, and opens a process of self-valorization and self-determination" (2012: 49). The influence of collective action on gender equality and women's empowerment has not yet been sufficiently empirically examined (Lauren Pandolfelli, Ruth Meinzen-Dick, and Stephan Dohrn 2005) and further feminist research in this matter is required. A possible starting point could be identifying similarities and differences in the meaning and influence of gender in shaping norms, rules, and shared strategies, and conversely, the impact of institutions on gender equality, as discussed in the previous paragraph. The study could show a more complete 
spectrum of the functioning of commons, demonstrating both accomplishments and deficits in achieving gender equality in common-pool resources management. Two entry points have been made in this spectrum. Firstly, Joni Lovenduski (1998) suggested the following five elements in analyzing gender and organizations: identity, sexuality, interaction, culture, and power, all the while emphasizing that all institutions are implicated in shaping gender relations. Secondly, the Social Institutions and Gender Index delves even deeper into gender analysis by capturing discriminatory social institutions (OECD 2012). It specifies fourteen variables, grouped into five subindices, namely: discriminatory family code, restricted physical integrity, son bias, restricted resources and entitlements, and restricted civil liberties. Both of these entry points can be developed further, not only theoretically, but also empirically, to contribute to the discussion on a gender perspective and institutions affecting the performance of common-pool resources. Finally, the commons as property rights no longer occur solely as rural natural common-pool resources but can be found in cities and digital space. This fact creates a greater need for the conceptualization and theorization of the commons and common governance structures from a variety of viewpoints in the future.

\section{CONCLUSION}

The subject of the commons has been widely examined and described in literature by ethnographers and sociologists, discussed at scientific conferences, and put into practice. However, the commons should reflect the values missing in the current state of affairs in order to be perceived as an alternative to the private-public division of goods and services. One such value is gender equity. The inclusion of gender in hypotheses, study design, research questions, and variables can give a more complete picture of women's position and role in governing the commons, their interests and needs, relationships between women and men (gender composition of groups), and division of labor as well as access to and control over resources. The contribution of my paper is the difficult task of locating gender in the work of one of the forerunners in the field of commons, and demonstrating thoughtful ways for its incorporation. I have employed content and discourse analyses of Ostrom's selected texts that have been analyzed from a gender perspective for the first time. I am aware that there are numerous ways to examine someone's work for gender inclusion and different ways to read gender into someone's work, so the outcomes of my analysis, demonstrating Ostrom's 
lack of interest in gender issues, also allow us to identify other important concerns she emphasizes in her publications such as planet sustainability or poverty. Her interdisciplinary work methods as well as her focusing on concrete problems of real people in communities have won recognition. She developed unique frameworks to examine communities and, for years, lead the Workshop in Political Theory and Policy Analysis for students and academics interested in her research. All these elements opened the doors for many social scientists that might continue her research and examine, among other issues, gender and relations of power, democracy, and trust in the commons as well as many other significant issues.

Zofia Lapniewska Research Training Group "Gender as a Category of Knowledge" Center for Transdisciplinary Gender Studies Humboldt-Universität zu Berlin Georgenstr. 47, 10117 Berlin, Germany

\section{NOTES ON CONTRIBUTOR}

Zofia Lapniewska, $\mathrm{PhD}$ in Economics, is an academic teacher, independent researcher, and trainer. Currently, she is WiSE Post-Doctoral Fellow at Glasgow Caledonian University, UK. Her areas of scientific interest are feminist economics, new institutional economics, and the theory of commons.

\section{ACKNOWLEDGMENTS}

The Stipend of the Fritz Thyssen Foundation for the research on which this paper is based is gratefully acknowledged [grant number Az. 40.13.0.008]. I thank Claudia Bruns and Konrad Hagedorn from Humboldt-Universität zu Berlin for their institutional support, Charlotte Hess for her thoughtful feedback on the study, and Stefan Łapniewski for his careful editing, and my partner Katarzyna Puzon for her support and encouragement. I would also like to thank the reviewers for their insightful comments that helped to improve the manuscript. 


\section{NOTES}

${ }^{1}$ Elinor Ostrom's curriculum vitae can be found at the Indiana University website: ostromworkshop.indiana.edu/founders/lostromev.htm.

${ }^{2}$ In my research, I initially planned to analyze Ostrom's individually authored publications to determine the subjects on which she particularly focused her attention, to hear her voice not influenced by other coauthors. However, any development in science is based on collaboration and here Elinor Ostrom was no exception. More than 170 coauthored positions, including 26 books, can be found in her CV alone. ${ }^{1}$ Due to restrictions on time and resources I was not able to examine this coauthored part of her oeuvre, but I recognize the need for conducting such a holistic study in the future.

${ }^{3}$ I checked the accessibility of all the Ostrom's papers and monographs in English listed on her CV. Unfortunately, some texts could not be found in the scientific databases, were not present in any of the Berlin's libraries, nor could they be purchased. Seven of the scanned publications could not be encoded by ATLAS.ti software in a text format, therefore they were excluded. As a result, I have assembled a body of 102 texts by Elinor Ostrom.

\section{REFERENCES}

Acker, Joan. 1990. "Hierarchies, Jobs, Bodies: A Theory of Gendered Organizations." Gender and Society 4(2): 139-158.

—. 1992. "Gendered Institutions. From Sex Roles to Gendered Institutions." Contemporary Sociology 21(5): 565-569.

Berg, Bruce L. 2007. Qualitative Research Methods for the Social Sciences. 6th ed. Boston, MA: Allyn and Bacon.

Bravo-Baumann, Heidi. 2000. Capitalisation of Experiences on the Contribution of Livestock Projects to Gender Issues. Bern: Working Document Swiss Agency for Development and Cooperation.

Brünner, Gisela and Gabriele Graefen. 1994. "Einleitung: zur Konzeption der funktionalen Pragmatik" [Introduction: the Concept of Functional Pragmatics], in: Gisela Brünner and Gabriele Graefen, eds. Texte und Diskurse [Texts and discourses], pp. 7-24. Opladen, Germany: Westdeutscher Verlag.

Butler, Judith. 1999 (1990). Gender Trouble. New York: Routledge.

Cardenas, Juan Camilo. 2000. "How Do Groups Solve Local Commons Dilemmas? Lessons from Experimental Economics in the Field." Environment, Development, and Sustainability 2: $305-22$.

Casari, Marco and Charles Plott. 2003. "Decentralized Management of Common Property Resources: Experiments with a Centuries-Old Institution." Journal of Economic Behavior and Organization 51: 217-247.

Chant, Sylvia. 2003. New Contributions to the Analysis of Poverty: Methodological and Conceptual Challenges to Understanding Poverty from a Gender Perspective. CEPAL - SERIE Mujer y 
desarrollo 47. Santiago: United Nations.

Christie, Christine. 2000. Gender and Language: Towards a Feminist Pragmatics. Edinburgh: Edinburgh University Press.

Code, Lorraine. 1996. "What Is Natural about Epistemology Naturalized?" American Philosophical Quarterly 33(1): 1-22.

Costanza, Robert, Bobbi Low, Elinor Ostrom, and James Wilson (Eds.) 2000. Institutions, Ecosystems, and Sustainability. Boca Raton, FL: CRC Press.

Cox, Michael, Elinor Ostrom, and James M. Walker. 2007. "Trust in Private and Common Property Experiments." Paper presented at the panel on "Fairness Economics and Political Economy" at the 103rd American Political Science Association Annual Meetings, Chicago, Illinois, August 30-September 2.

Crawford, Sue E. S., and Elinor Ostrom. 1995. "A Grammar of Institutions.” American Political Science Review 89(3): 582-600.

Demsetz, Harold. 1967. "Toward a Theory of Property Rights.” American Economic Review 57(2): $347-59$.

Dijk, Teun A. Van. 2001. "Critical Discourse Analysis," in: Deborah Schiffrin, Deborah Tannen, and Heidi E. Hamilton, eds. Handbook of Discourse Analysis, pp. 352-71. Oxford: Blackwell.

Federici, Silvia. 2004. Caliban and the Witch: Women, The Body, and Primitive Accumulation. New York: Autonomedia.

—. 2012. "Feminism and the Politics of the Commons," in: David Bollier and Silke Helfrich, eds. The Wealth of the Commons: A World Beyond Market and State, pp. 45-54. Amherst, MA: Levellers Press.

Ferber, Marianne A. 1997. "Gender and the Study of Economics: A Feminist Critique," in: Robin L. Bartlett, ed. Introducing Race and Gender into Economics, pp. 162-70. London: Routledge.

Folbre, Nancy. 1994. Who Pays for the Kids? Gender and the Structures of Constraint. London: Routledge.

—. 2009. "The Economics Club." The New York Times, October 19, http://economix.blogs.nytimes.com/2009/10/19/the-economics-club/

Giddens, Anthony. 1999. "Modernity and Self-Identity: Tribulations on the Self" in: Adam Jaworski and Nikolas Coupland, eds. The Discourse Reader. London: Routledge.

Graham, Laurel. 1990. A Year in the Life of Dr. Lillian Moller Gilberth: Four Representations of the Struggle of a Woman Scientist. Paper presented at the Gregory Stone Symposium, St. Petersburg Beach, Florida, January 3-4.

Hankivsky, Olena. (Ed.) 2012. An Intersectionality-Based Policy Analysis Framework. Vancouver, BC: Institute for Intersectionality Research and Policy, Simon Fraser University.

Hardin, Garrett J. 1968. "The Tragedy of the Commons.” Science 162: 1243-8.

Jagger, Pamela. 2008. "Forest Incomes after Uganda's Forest Sector Reform: Are the Rural Poor Gaining?" CAPRi Working Paper 92. International Food Policy Research Institute.

Jennings, Ann L. 1993. "Public or Private? Institutional Economics and Feminism," in: Marianne A. Ferber and Julie Nelson, eds. Beyond Economic Man: Feminist Theory and Economics, pp. 
111-29. Chicago: University of Chicago Press.

Karl, Marilee. 1997. Higher Agricultural Education and Opportunities in Rural Development for Women - An Overview and Summary of Five Case-Studies. Rome: Food and Agriculture Organization of the United Nations.

Korten, Fran. 2010. "Elinor Ostrom Wins Nobel for Common(s) Sense.” YES! Magazine, cms.yesmagazine.org/issues/america-the-remix/elinor-ostrom-wins-nobel-for-common-ssense?b_start:int $=0$.

Levi, Margaret. 2010. “Annual Reviews Conversations Presents: An Interview with Elinor Ostrom.” Annual Reviews, http://www.annualreviews.org/userimages/ContentEditor/1326999553977/ElinorOstromTrans cript.pdf

Litosseliti, Lia. 2006. Gender and Language: Theory and Practice. London: Hodder Education.

Litosseliti, Lia, and Jane Sunderland. 2002. Gender Identity and Discourse Analysis. Amsterdam: John Benjamins Publishing Company.

Longino, Helen. 1990. Science as Social Knowledge. Princeton NJ: Princeton University Press.

Lovenduski, Joni. 1998. "Gendering Research in Political Science." Annual Review of Political Science 1: 333-56.

May, Ann Mari and Gale Summerfield. 2012. "Creating a Space where Gender Matters: Elinor Ostrom (1933-2012) talks with Ann Mari May and Gale Summerfield." Feminist Economics 18(4): $25-37$.

Momsen, Janet. 2002. "NGOs, Gender and Indigenous Grassroots Development.” Journal of Development Studies 14: 1-9.

Mwangi, Esther, Ruth Meinzen-Dick, and Yan Sun. 2011. "Gender and Sustainable Forest Management in East Africa and Latin America." Ecology and Society 16(1): 17.

Nelson, Julie. 1992. "Gender, Metaphor, and the Definition of Economics." Economics and Philosophy 8: 103-25.

—. 1995. Feminism, Objectivity, and Economics. London: Routledge.

— 1996. "The Masculine Mindset of Economic Analysis." Chronicle of Higher Education 42(42): B3.

—. 2013. "Would Women Leaders Have Prevented the Global Financial Crisis? Teaching Critical Thinking by Questioning a Question." Paper 40, Economics Faculty Publication Series. University of Massachusetts Boston. scholarworks.umb.edu/econ_faculty_pubs/40

North, Douglass C. 1990. Institutions, Institutional Change, and Economic Performance. New York: Cambridge University Press.

Organisation for Co-operation and Development (OECD). 2012. "Social Institutions and Gender Index." Understanding the Drivers of Gender Inequality. genderindex.org

Ostrom, Elinor. 1965. "Public Enterpreneurship: A Case Study in Ground Water Management," Ph.D. Dissertation, University of California at Los Angeles.

—. 1990. Governing the Commons: The Evolution of Institutions for Collective Action. Cambridge: Cambridge University Press. 
—. 1998. "A Behavioral Approach to the Rational Choice Theory of Collective Action: Presidential Address, American Political Science Association, 1997.” American Political Science Review $92(1): 1-22$.

—. 1999. "Coping With Tragedies of the Commons." Annual Review of Political Science 2: 493535.

—. 2000. "Crowding out Citizenship.” Scandinavian Political Studies 23(1): 3-16.

—. 2005a. "Policies That Crowd out Reciprocity and Collective Action," in Herbert Gintis, Samuel Bowles, Robert Boyd, and Ernst Fehr, eds. Moral Sentiments and Material Interests: The Foundations of Cooperation in Economic Life, pp. 253-75. Cambridge MA: MIT Press.

—. 2005b. "Developing a Method for Analyzing Institutional Change." Paper presented at "Who Should Do What in Environmental Governance: Institutions and Constraints" Symposium, Porto Conte Ricerche Centre in Tramariglio (Alghero), Italy, September 21-24.

—. 2006. "The Value-Added of Laboratory Experiments for the Study of Institutions and CommonPool Resources." Journal of Economic Behaviour and Organization 61: 149-63.

_. 2009a. "A Polycentric Approach for Coping with Climate Change." Policy Research Working Paper 5095, World Bank, Development Economics.

—. 2009b. "What is Social Capital?" in Viva Ona Bartkus and James H. Davis, eds. Social Capital: Reaching Out, Reaching In, pp. 17-38. Cheltenham, UK: Edward Elgar.

- 2010. "Polycentric Systems for Coping with Collective Action and Global Environmental Change." Global Environmental Change 20: 550-7.

Pal, Amitabh. 2010. "Elinor Ostrom.” Progressive Magazine, http://www.progressive.org/elinor_ostrom_interview.html

Pandolfelli, Lauren, Ruth Meinzen-Dick, and Stephan Dohrn. 2005. Gender and Collective Action: A Conceptual Framework for Analysis. International Research Workshop on "Gender and Collective Action,” International Food Policy Research Institute, Chiang Mai, Thailand, October 17-21.

Pauwels, Anne. 1998. Women Changing Language. New York: Longman.

Peterson Janice and Margaret Lewis. (Eds.) 1999. The Elgar Companion to Feminist Economics. Cheltenham, UK: Edward Elgar.

Podlashuc, Leo. 2009. "Saving Women: Saving the Commons," in: Ariel Salleh, ed. Eco-Sufficiency and Global Justice: Women Write Political Ecology, pp. 268-290. New York: Macmillan Palgrave.

Porter, Marilyn, and Ellen Judd. (Eds.) 1999. Feminists Doing Development. New York: Zed.

Powell, Walter W., and Paul J. DiMaggio. 1991. The New Institutionalism in Organizational Analysis. Chicago: Chicago University Press.

Reinharz, Shulamit. 1992. Feminist Methods in Social Research. New York: Oxford University Press.

Ridgeway, Cecilia, and Shelley Correll. 2004. "Unpacking the Gender System: A Theoretical Perspective on Gender Beliefs and Social Relations." Gender and Society 18(4): 510-31.

Schwartz-Shea, Peregrine. 2010. "Beyond the Tragedy of the Commons. A Discussion of Governing the Commons: The Evolution of Institutions for Collective Action." Perspectives on Politics 
8(2): 587-90.

Schwartz-Shea, Peregrine, and Dvora Yanow. 2002. "'Reading' 'Methods' 'Texts': How Research Methods Texts Construct Political Science.” Political Research Quarterly 55 (2): 457-86.

Sen, Amartya K. 1974. "Choice, Orderings, and Morality,” in Stephan Körner, ed. Practical Reason: Papers and Discussions, pp. 54-67. Oxford: Blackwell.

—. 1977. "Rational Fools: A Critique of the Behavioral Foundations of Economic Theory." Philosophy and Public Affairs 6: 317-44.

Smith, Adam. 2009. "Interview." www.nobelprize.org/nobel_prizes/economicsciences/laureates/2009/ostrom-telephone.html.

Sotiropoulou, Irene. 2012. "Women in Alternative Economy or What Do Women Do without Official Currency?" www.academia.edu/2330012/WOMEN_IN_ALTERNATIVE_ECONOMY_OR_WHAT_DO _WOMEN_DO_WITHOUT_OFFICIAL_CURRENCY.

Sunderland, Jane. 2004. Gendered Discourses. London: Palgrave Macmillan.

Talbot, Mary. 1998. Language and Gender: An Introduction. Cambridge, UK: Polity Press.

Taylor, Frank. 2003. "Content Analysis and Gender Stereotypes in Children's Books." Teaching Sociology 31(3): 300-11.

Thelen, Kathleen. 2003. "How Institutions Evolve: Insights from Comparative Historical Analysis," in James Mahoney and Dietrich Rueschemeyer, eds. Comparative Historical Analysis in the Social Sciences, pp. 208-40. Cambridge: Cambridge University Press.

Tool, Marc R. (Ed.) 1993. Institutional Economics: Theory, Method, Policy. Boston: Kluwer Academic Publishers.

Vatn, Arild. 2005. Institutions and the Environment. Cheltenham UK: Edward Elgar.

Westermann, Olaf, Jacqueline Ashby, and Jules Pretty. 2005. "Gender and Social Capital: The Importance of Gender Differences for the Maturity and Effectiveness of Natural Resource Management Groups." World Development 33(11): 1783-99.

Williamson, Oliver E. 1975. Markets and Hierarchies: Analysis and Antitrust Implications. New York: Free Press.

Wodak, Ruth. (Ed.) 1997. Gender and Discourse. London: Sage Publications.

Wünstel, Michael. 2013. "Hauptseite zum Thema Tauschringe" [Homepage of Exchange Networks]. http://www.tauschring.de 